\title{
Persistence with treatment in patients with Wilson disease
}

\section{Wytrwałość w leczeniu wśród chorych na chorobę Wilsona}

\author{
Wojciech Masetbas', Grzegorz Chabik², Anna Członkowska² \\ IKatedra i Zakład Farmakologii Doświadzzalnej i Klinizznej, Warszawski Uniwersyłtet Medyczny \\ 2|| Klinika Neurologii, Instytut Psychiatrii i Neurologii w Warszawie
}

Neurologia i Neurochirurgia Polska 2010; 44, 3: 260-263

\begin{abstract}
Background and purpose: Wilson disease is genetically induced failure of copper metabolism. If untreated, it may lead to death within several years from the onset of symptoms. Use of medication should therefore continue over the whole span of the patient's life after the diagnosis. Clinical observations show that patients with Wilson disease frequently stop the treatment. The aim of our study was to assess how drug compliance (defined as persistence with drug use) translates into the total well-being of patients with Wilson disease.
\end{abstract}

Material and methods: Patients diagnosed with Wilson disease and observed in our outpatient clinics were asked to fill in the self-completed questionnaire. Questions were related to demographic data, characteristics of the disease, methods of treatment and persistence with treatment, subjective assessment of health status and treatment efficacy. The EQ-5D questionnaire with a visual analogue scale of wellbeing was also used.

Results: Responses were obtained from 120 subjects but only 104 questionnaires could be further processed. Our analysis did not reveal differences in persistence with d-penicillamine and zinc sulphate use or efficacy of prescribed medication. We found, however, that regardless of the medication used, persistence with treatment resulted in significantly better results of self-assessment (total improvement in $39.7 \%$ vs. $7.7 \%$ in the non-persistent group, $p=0.003$; partial improvement in $53.8 \%$ vs. $30.8 \%$, respectively, $p=0.045$; and dete-

\section{Streszczenie}

Wstęp i cel pracy: Choroba Wilsona jest genetycznie uwarunkowanym zaburzeniem metabolizmu miedzi. U osób nieleczonych może doprowadzić do zgonu w ciagu kilku lat od wystąpienia pierwszych objawów. Stosowanie leków jest zatem długotrwałe i powinno odbywać się przez całe dalsze życie chorego. Obserwacje kliniczne pokazują, że pacjenci z chorobą Wilsona często przerywają terapię. Celem naszego badania była ocena, w jaki sposób przestrzeganie zaleceń lekarza odnoszących się do farmakoterapii (definiowane głównie jako wytrwałość w przyjmowaniu leku) przekłada się na stan pacjentów z chorobą Wilsona.

Materiał i metody: Wśród chorych na chorobę Wilsona leczonych w naszej poradni przeprowadzono badanie ankietowe. Pacjenci samodzielnie wypełniali kwestionariusz zawierający pytania o dane demograficzne, charakterystykę choroby, sposób leczenia, wytrwałość w leczeniu, subiektywną ocenę stanu zdrowia i skuteczności terapii. Wykorzystano również kwestionariusz EQ-5D ze wzrokową skalą oceny samopoczucia.

Wyniki: W badaniu wzięło udział 120 chorych, ale tylko 104 kwestionariusze nadawały się do oceny. Przeprowadzona analiza nie wykazała różnic w wytrwałości przyjmowania d-penicylaminy oraz soli cynku ani różnic w skuteczności obu leków. Stwierdzono jednak, że niezależnie od przyjmowanego leku, wytrwałość w jego stosowaniu wiąże się ze znacząco lepszą samodzielną oceną stanu zdrowia w badaniu kwestionariuszowym (pełna poprawa nastąpiła u 39,7\% przyj-

Correspondence address: prof. Anna Członkowska, II Klinika Neurologii, Instyłut Psychiatrii i Neurologii,

ul. Sobieskiego 9, 02-957 Warszawa, e-mail: czlonkow@ipin.edu.pl

Received: 31.01.2010; accepted: 13.05.2010 
rioration: none in the persistent group vs. $42.3 \%$ in the nonpersistent group, $p<0.0001)$.

Conclusions: Lack of persistence with use of prescribed medication is rather frequent among patients with Wilson disease. Lack of compliance decreases chances for improvement and might be the cause of clinical deterioration.

Key words: Wilson disease, persistence, effects of treatment.

\section{Introduction}

Wilson disease is genetically induced failure of copper metabolism caused by mutation of the $A T P 7 B$ gene. It is inherited in an autosomal recessive pattern. The disease leads to inappropriate management of copper, which initially accumulates in the liver and after exhausting its storage capacity infiltrates the brain, cornea (Kayser-Fleischer ring) and kidneys [1].

If untreated, the disease usually leads to death within several years from the onset of symptoms [2]. In the majority of cases, early diagnosis and treatment help to prevent irreversible damage [3]. Treatment is based on products that eliminate copper from the body or prevent its absorption via the gastrointestinal tract [4]. Most often used are chelating agents (d-penicillamine, trientine), zinc preparations (zinc sulphate) and molybdenum (ammonium tetrathiomolybdate). Intake of medicines should continue over the whole span of the patient's life after the diagnosis.

There are no large-scale, randomized controlled studies proving the benefit of any particular treatment over others [4]. Patient compliance with prescribed medication poses a problem in many diseases requiring prolonged treatment. It is usually analysed in terms of adherence (compliance in drug use as prescribed by the physician) and persistence (defined as the length of time for which the patient takes the prescribed medication in the required dose) $[5,6]$.

Clinical observations show that patients with Wilson disease, like many other patients with chronic diseases, frequently stop the treatment. Publications analysing the frequency as well as the impact of poor compliance on treatment failure are lacking. mujących leki bez dłuższych przerw wobec $7,7 \%$ w grupie niestosującej się do zaleceń lekarza, $p=0,003$; częściowa poprawa odpowiednio u $53,8 \%$ i $30,8 \%, p=0,045$, a pogorszenie nie miało miejsca u żadnego $\mathrm{z}$ chorych przyjmujących lek wobec $42,3 \%$ w grupie, która nie przyjmowała leku stale, $p<0,0001)$.

Wnioski: Brak wytrwałości w leczeniu występuje dość często wśród pacjentów z chorobą Wilsona. Niestosowanie się do zaleceń dotyczących przyjmowania leków zmniejsza szansę na wystąpienie poprawy i może być przyczyną pogorszenia stanu klinicznego.

Słowa kluczowe: choroba Wilsona, wytrwałość w leczeniu, efekty leczenia.

The aim of the study was to evaluate how drug compliance (defined by us as persistence with drug use) translates into the total well-being of patients with Wilson disease. It was based on self-completed questionnaires.

\section{Material and methods}

The study was compliant with principles outlined in the "Declaration of Helsinki" [7].

In September 2006, a self-assessment questionnaire was obtained from 120 subjects with Wilson disease, who planned to form an association of patients affiliated at the Institute of Psychiatry and Neurology of Warsaw, Poland. The questionnaire included: (1) demographic data; (2) questions on symptoms at diagnosis, date of diagnosis, date of the start of treatment, prescribed medication and regimen; (3) questions assessing persistence (frequency of periods of not taking medication and their length); (4) subjective assessment of health status and effectiveness of treatment (total or partial improvement, no change, deterioration); (5) EQ-5D questionnaire with visual analogue scale of well-being (with 100 reflecting the best possible result and 0 the worst one) [7].

The response to the questionnaire was completely voluntary and non-responders were not devoid of any rights. Obtained data were analysed in two-tailed Fisher's exact test and unpaired Student's t-test.

\section{Results}

Responses were obtained from 120 subjects; some of them were largely incomplete, however, and only 104 questionnaires ( $86.7 \%$ of targeted) were used for analysis. 
Among analysed subjects 57 were females (54.8\%). Diagnosis of Wilson disease was primarily based on neurological symptoms (68 subjects, 65.3\%), with 31 participants (29.8\%) reporting hepatic symptoms. Five subjects were pre-symptomatic and diagnosis was based on family screening.

The mean length of drug therapy was 10.3 years (SD, 4.4), including 10.2 years (SD, 4.1) among women and 10.3 years $(\mathrm{SD}, 4.6)$ in men $(p=0.9)$. At the time of assessment, d-penicillamine was the most frequently used medication. It was being taken by 57 patients $(54.8 \%)$. The most frequently used dose was $1000 \mathrm{mg}(1-2-1$ tablets before meals). Additionally, 47 subjects (45.2\%) had been using zinc sulphate with mean daily dose of $180 \mathrm{mg}$ (range, 135-270 mg) (1-2-1 tablets before meals).

Persistence with use of d-penicillamine and zinc sulphate was similar $(72.7 \%$ and $76.5 \%$, respectively, $p=0.82)$. Many patients, however, were not able to provide detailed information on frequency and length of breaks in drug use. We believe that this concerned equally those who used d-penicillamine and those who took zinc sulphate.

Effects of treatment were also similar (Table 1). Two patients had recently switched to d-penicillamine from trientine and were not included in this analysis. We found, however, that regardless of the medication, persistence with drug use resulted in significantly better results of self-assessment (Table 2). It is worth noting that among 68 patients with neurological symptoms, $61(90 \%)$ were persistent with the drug treatment. Among subjects with primarily hepatic manifestation of the disease, 17 (55\%) complied with the persistence of drug use. None of 5 presymptomatic patients was taking medication as prescribed.

\section{Discussion}

Our study revealed that as many as $25 \%$ of all subjects were not persistent with taking the prescribed medication. Those patients more frequently reported clini-

Table 1. Effect of treatment with d-penicillamine and zinc sulphate on well-being of patients with Wilson disease*

\begin{tabular}{|c|c|c|c|}
\hline & $\begin{array}{l}\text { Patients taking } \\
\text { d-penicillamine } \\
(n=55)\end{array}$ & $\begin{array}{l}\text { Patients on zinc } \\
\text { sulphate therapy } \\
(n=47)\end{array}$ & $p$-value \\
\hline Total improvement & $17(30.9 \%)$ & $15(31.9 \%)$ & 1.0 \\
\hline Partial improvement & $27(49.1 \%)$ & $22(46.8 \%)$ & 0.84 \\
\hline No change & $5(7.5 \%)$ & $7(14.9 \%)$ & 0.59 \\
\hline Deterioration & $6(10.9 \%)$ & $3(6.4 \%)$ & 0.5 \\
\hline $\begin{array}{l}\text { VAS assessment of well-being; } \\
\text { mean (SD) }\end{array}$ & $71.51(20.13)$ & $77.04(17.46)$ & $\begin{array}{c}0.1449 \\
\text { (mean difference, 5.3, } \\
\text { 95\% CI: }-12.99-1.94 \text { ) }\end{array}$ \\
\hline
\end{tabular}

*Patients who had recently switched to d-penicillamine from trientine dihydrochloride were not included in this analysis

$S D$ - standard deviation, $C I-$ confidence interval

Table 2. Effect of persistence in drug use (irrespective of prescribed medication) on the well-being of patients with Wilson disease

\begin{tabular}{|c|c|c|c|}
\hline & $\begin{array}{c}\text { Persistent } \\
\text { patients } \\
(n=78 ; 75 \%)\end{array}$ & $\begin{array}{c}\text { Non persistent } \\
\text { patients } \\
(n=26 ; 25 \%)\end{array}$ & p-value \\
\hline Total improvement & $31(39.7 \%)$ & $2(7.7 \%)$ & 0.003 \\
\hline Partial improvement & $42(53.8 \%)$ & $8(30.8 \%)$ & 0.045 \\
\hline No change & $5(6.4 \%)$ & $5(19.2 \%)$ & 0.116 \\
\hline Deterioration & 0 & $11(42.3 \%)$ & $<0.0001$ \\
\hline $\begin{array}{l}\text { VAS assessment of well-being; } \\
\text { mean (SD) }\end{array}$ & $75.93(15.77)$ & $67.97(24.25)$ & $\begin{array}{c}0.0564 \\
\text { (mean difference, } 7.96 ; \\
95 \% \mathrm{CI}:-0.23-16.14\end{array}$ \\
\hline
\end{tabular}

SD - standard deviation, CI - confidence interval, VAS - Visual Analogue Scale 
cal deterioration, and less often partial or total improvement. Assessment based on self-reported questionnaires usually overestimates the actual rate of compliance [6]. Most frequently the reason is not due to unauthorized modification of therapy by the patient or deliberate reporting of false results, but rather forgetfulness $[9,10]$. Patients who have forgotten to take their medication would most probably forget that they did not comply with the drug treatment $[11,12]$. This effect seemed to be similar across different treatments.

We did not evaluate the reason for non-persistence in the present study. Patients who start treatment in our department receive full information about the need for full compliance. Clinical observations show, however, that psychiatric symptoms are a rather frequent reason for unauthorized stopping or modification of drug therapy [13]. This problem might also be a frequent reason for not attending scheduled visits [14].

\section{Conclusions}

1. Lack of persistence in use of prescribed medication is rather frequent among patients with Wilson disease.

2. Lack of compliance with prescribed medication decreases chances for improvement. It also seems to be the cause of clinical deterioration.

3. Reasons for non-compliance require more detailed study.

\section{Disclosure}

Authors report no conflict of interest.

\section{References}

1. Ala A., Walker A.P., Ashkan K., et al. Wilson's disease. Lancet 2007; 369: 397-408.

2. Członkowska A., Tarnacka B., Litwin T., et al. Wilson's disease - cause of mortality in 164 patients during 1992-2003 observation period. $J$ Neurol 2005; 252: 698-703.

3. Machado A., Chien H.F., Deguti M.M., et al. Neurological manifestations in Wilson's disease: report of 119 cases. Mov Disord 2006; 21: 2192-2196

4. Członkowska A., Gajda J., Rodo M. Effects of long-term treatment in Wilson's disease with d-penicillamine and zinc sulphate. J Neurol 1996; 243: 269-273.

5. Simpson S.H., Eurich D.T., Majumdar S.R., et al. A metaanalysis of the association between adherence to drug therapy and mortality. BMJ 2006; 333: 15-18.

6. White H.D. Adherence and outcomes: it's more than taking the pills. Lancet 2005; 366: 1989-1991.
7. http://www.wma.net/en/30publications/10policies/b3/index.html 8. http://www.euroqol.org/eq-5d/what-is-eq-5d.html

9. Miller N.H. Compliance with treatment regimens in chronic asymptomatic diseases. Am J Med 1997; 102: 43-49.

10. Fincke B.G., Miller D.R., Spira A. 3rd, et al. The interaction of patient perception of overmedication with drug compliance and side effects. J Gen Intern Med 1998; 13: 182-185.

11. DiMatteo M.R., Lepper H.S., Croghan T.W., et al. Depression is a risk factor for noncompliance with medical treatment. Arch Intern Med 2000; 160: 2101-2107.

12. Sokol M.C., McGuigan K.A., Verbrugge R.R., et al. Impact of medication adherence on hospitalization risk and healthcare cost. Med Care 2005; 43: 521-530

13. Leeman E. The costs of compliance. J Am Acad Psychoanal Dyn Psychiatry 2007; 35: 179-187.

14. Tay S.E. Compliance therapy: an intervention to improve inpatients' attitudes toward treatment. $J$ Psychosoc Nurs Ment Health Serv 2007; 45: 29-37. 